\title{
The impact of foreign direct investment in the Western Balkans
}

\author{
Dr. Alma Zisi \\ University "Aleksander Moisiu",Durrës, Square No. 1, Currila, Durrës, Albania \\ Dr. Armela Anamali \\ University "Aleksander Moisiu",Durrës, Square No. 1, Currila, Durrës, Albania
}

Doi:10.5901/ajis.2016.v5n3s1p584

\section{Abstract}

This paper intends to analyse the economic growth of Western Balkan Countries. Economic growth can be defined as the nation's capacity to produce goods and service. The capability of the country depends mostly by its resources, such as level of technology, labour force, capital, productivity, etc. At first, our analysis will focus on a macroeconomic overview of these countries, and afterwards to the economic growth trends in these countries, given the fact these countries have joined ${ }^{1}$ or are preparing to join the European Union. Recently, the role of foreign direct investment in the host countries' economies is more studies. In this paper, will deal with the performance and role of FDls in economic growth of the Western Balkan countries.

Keywords: Western Balkans country, economic growth, FDl;

\section{Introduction}

The first studies on economic growth are the neoclassical models. Solow $(1956,1957)$ applied the analysis of growth within the neoclassical model. Neoclassical model analysed the huge impact of technological progress on economic growth while the new growth theories were mainly focused on the creation of technological knowledge and transmission thereof.

In her work examines whether FDIs in different sectors have different effects on economic growth. Thus, the empirical surveys reveal that FDIs in the primary sector have the tendency to have a negative effect on economic growth, while FDIs in the manufacturing sector have a positive effect.

Later on (L. Alfaro, et al 2006) presented the link between the theoretical and the empirical literature. The model relies on the role of financial markets, FDIs and economic growth. They reached in the conclusion that countries with developed financial markets stimulate more FDIs; therefore have a positive impact on economic growth.

Recent years, researchers have argued that FDIs can promote advanced technology having an impact on the host country's economic growth; for this reason, a greater attraction of foreign investments is noticed. For example, pay more attention to technology transfer through multinational corporations and cooperation among foreign and local firms.

argues that the transfer of technology through multinational corporations contributes to increase productivity in developed countries, but not in the least developed countries. This happens because countries benefiting from technology transfer should necessarily have a minimum level of human capital.

Foreign direct investment also impact on the labour market through new jobs creation. Among the most important and long-term effects of FDI are technology transfer and technical know-how, which are reflected in human capital. If foreign investment are made in activities that local firms have limited experience, FDls have impact on important knowledge transfer, in terms of training, practices, management techniques and organizational behaviour. FDIs can also increase productivity through research and development (R \& D) having a positive impact on increase of production .

In their work treated together economic growth models stemming from the basic Solow model of production function and developed later on by by, and. They tested the effects of FDIs on economic growth in 25 countries of Central and Eastern Europe and the former Soviet Union from 1990-1998. Their main finding was that FDIs has a positive and significant impact on economic growth.

\footnotetext{
${ }^{1}$ Croatia as acceded to EU
} 


\section{Macroeconomic Situation of the Western Balkan Countries}

Albania is part of the South-East European (SEE) countries, therefore it is important to analyse the key trends of economic, political and institutional development of these countries. The countries we taken in analysis are Albania, Bosnia-Herzegovina, Kosovo, Croatia, Montenegro, Macedonia and Serbia.

During 2013, the Albanian economy suffered a slight decline. Among the key factors that contributed to the economic decline of our country, we can mention public debt and weaknesses of financial sector due to bad loans.

Economic growth in Kosovo, in 2013, continued to be among the highest in the region, but it still remains the poorest country in Southeast Europe, as unemployment and poverty levels remain high.

Economic growth was 0.8 per cent for Bosnia-Herzegovina in 2013. It is forecasted that economic performance in this country to be better in 2014 , although economic and political reforms have not progressed as expectations, risking withdrawal of funds back from EU.

Also in Montenegro, the performance of the economy declined in 2013 as public debt rose significantly the recent years. In 2014, a growth of 2.5 per cent is forecasted due to improvements both in external and internal demand.

For Macedonia, economic situation appears to be better 2013, thanks to the continuous increase of foreign direct investment. Such foreign investments are expected to have a positive effect on economic growth in Macedonia in the following years. For 2014, growth is forecasted at 3 per cent.

The Serbian economy has not been indifferent to financial difficulties, either. Public debt exceeded 60 per cent of GDP and still continues to grow. Serious problems are reported in loan sector where bad loans comprise more than 20 per cent of total loans. For 2014, economic growth is forecasted at 1.3 per cent, a rate lower than in $2013^{2}$.

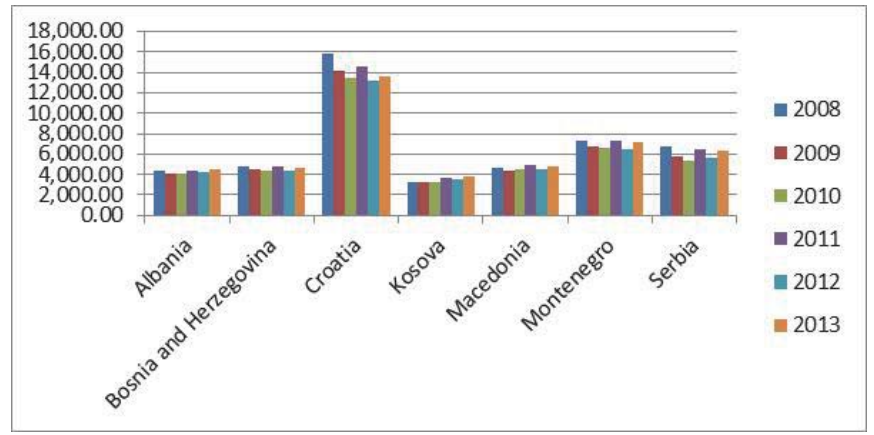

Graph 1: GDP per capita

Source: World Bank - GDP per capita

As seen from the graph above, only Croatia reveals the same GDP per capita as that of EU countries. Albania and Kosovo are ranked lower in terms of GDP per capita, which means that we have not achieved yet a good level of living, despite Albania has the potential to have a sustainable economic growth.

After 2009, all the countries of Eastern Europe experienced a significant decline in economic growth. The effects of the crisis are reflected in Figure 2, making it clear that economic growth has declined in each country.

According to graph 2, Kosovo has the fastest economic growth in the region, while Croatia and Serbia, which are countries with the largest economies, result with an annual growth rate of only 2 per cent. Serbia's economic growth remains at low levels due to legal and regulatory obstacles to business activities with regional countries ${ }^{3}$. 


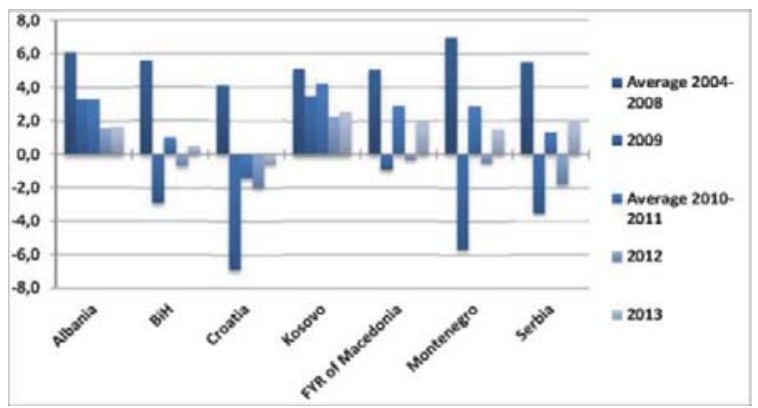

Graph 2. Economic growth of SEE countries

Source: WBIF (IMF) 2013

Graph 3 reflects the level of consumption, investment and net exports in SEE countries. In the graph it is noticeable, besides Croatia, all other countries consume considerable quantities of goods coming from imports. Net exports result, for all these countries with negative value, i.e. it is more imported than exported.

Huge consumption exceeds the total production in Bosnia-Herzegovina, Kosovo and Montenegro. It can be said that other countries, such as Albania, Macedonia and Serbia, show a tendency to consume about 95 per cent of GDP. Such high consumption means low savings to influence their investment. So, it is necessary to stimulate private and public investment in these countries.

According to the Spahn, Vukotic and O'Mahony (2013), this indicator stimulates the need to increase exportoriented strategies supported by structural reforms to increase productivity, market liberalization, and entry in foreign markets, scientific research, creativity and innovation.

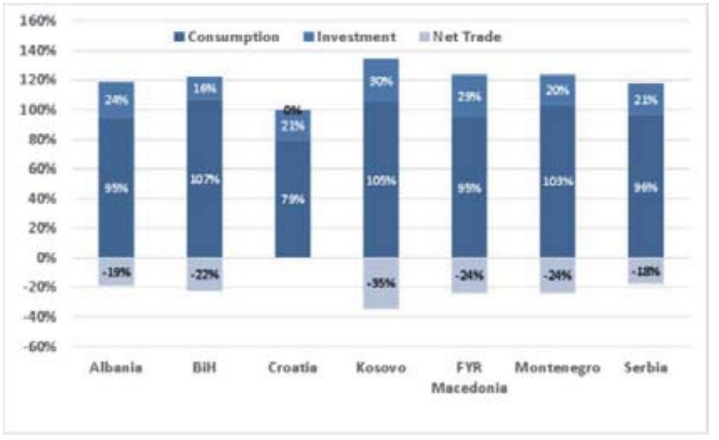

Graph 3. Consumption, investment and net trade

Source: WBIF (IMF), November 2013

\section{FDls}

Eastern European countries attracted a significant number of foreign direct investment thanks to good business climate, lower cost of labour, facility to access to European markets and, mainly, due to privatization of state-owned enterprises. However, after 2010, FDIs experienced a slight decrease in the SEE countries due to the financial crisis the investing countries were experiencing, which were mainly EU countries. In 2010, FDI inflows in Albania reached at 793 million Euros, while FDI flows continued to be stable in the following years. Croatia and Albania was the biggest recipient of inflows in the region for $2012^{4}$. 
From chart 4, it can is understood that FDIs flows were significantly reduced for Serbia in 2012 compared to a year earlier. For Macedonia also, there was a decline in FDIs in 2012, while in Bosnia and Herzegovina we notice an increase in FDI in 2012.

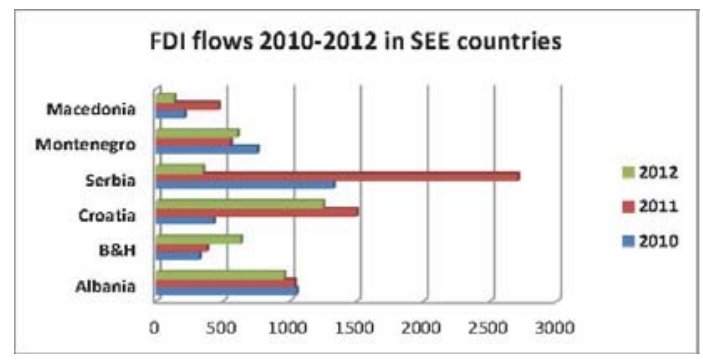

Graph 4. FDI flows in SEE Countries

Source: World Investment Report 2013

\section{Ease of doing business in SEE countries}

To attract more foreign investors, SEE countries have to be more competitive and productive. Economic Report ${ }^{5}$ for SEE countries addresses, among others, the ease of doing business in these countries. According to this report, such countries are recommended to accelerate structural reforms to encourage foreign investment in the country.

Significant improvements in ease of procedures for starting a business in these countries is observed. Privatization process shall have a positive effect in attracting foreign investors. However, these countries still have much work to do to reach a better climate for doing business.

The chart below shows that Macedonia is at first place for starting a business. In addition, Macedonia is trying to absorb investors in the field of electricity.

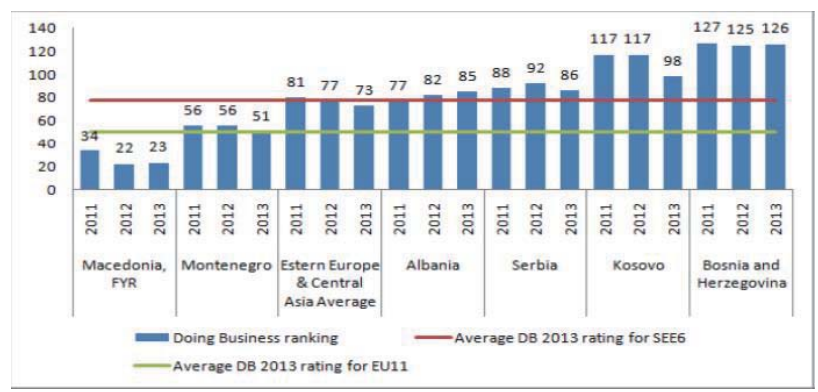

Graph 5. Ease of doing business in SEE countries

Source: WB Doing Business 2013,

As we discussed above, Albania has made progress in the ease of doing business. However, last year's ranking shows that Albania has deteriorated going to the 90th place, in terms of ease of doing business. ${ }^{6}$

Montenegro has a significant improvement in ease of tax payments. Montenegro was ranked 51st in 2013 from the 56th it was in 2012. Serbia has simplified significantly the procedures for starting a business, which has improved its ranking, moving from 92nd in 2012 to 88th in 2013. Kosovo has also improved the procedures for starting a business. Thus, from the 117th place it was ranked in 2012, she was the 98th place in 2013. Bosnia and Herzegovina had only a 
slight decline from 125th in 2012 to 126 th in 20137.

If we compare the Western Balkan countries with the global competitiveness, we will see that Montenegro if at the first place, followed by Macedonia. It is impressive how competitiveness of Bosnia and Herzegovina has increased in recent years, leaving Albania and Serbia behind.

Albania has experienced a slight decline in competitiveness in 2012-2013. However, we may say that the reforms undertaken by the Albanian governments have contributed positively to increase competition.

For Albania experiences an increase in competitiveness, compared to the region countries and beyond, it is necessary to improve the technological capabilities, good business climate, on-going investments in infrastructure and institutional consolidation ${ }^{8}$.

Graph 6 presents the ranking of Balkan countries as per global competitiveness report.

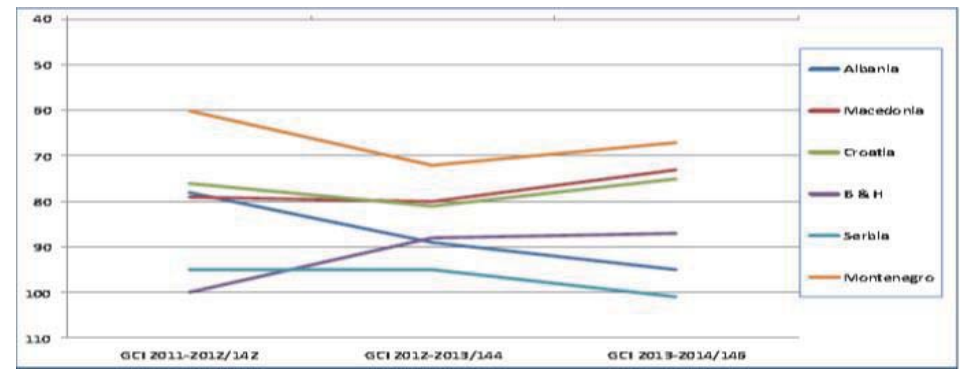

Graph 6. Ranking of Balkan countries

Source: 2014-2020 Business development and investment strategy

\section{Conclusions}

Foreign direct investments are very important for the economic development of the SEE countries; however it remains a continuous challenge for them to attract foreign investors. Their aspiration to access EU still poses a great challenge; therefore, it is absolutely necessary these countries have a close cooperation with one-another to achieve a better social and economic level.

Negotiations and agreements between these countries are intended to implement policies stimulating their economic growth. Thus, the OECD investment agreement for $\mathrm{SEE}^{9}$ provides support to all governments in the region to promote economic growth, sharing experiences and using appropriate instruments. This agreement aims to improve the business climate and continue promotion of foreign direct investment.

- Strengthening of regional relations to promote FDIs and following non-discriminatory policies;

- Increasing competitiveness in the private sector;

- Inclusive participation in the labour market;

- Strengthening the rule of law and minimization corruption, creating a more competitive environment for all private sector firms.

Among appropriate ways to promote foreign direct investment are: development of human capital, trade facilitation policies, regulatory reform, tax policy, infrastructure investments.

\section{References}

Alfaro, L. (2003). FDI and Growth: Does the sector matter? Harvard Business School

Alfaro, Chanda, Kalemli-Ozcan, dhe Sayek. 2006. "How does FDI Promote Economic Growth? Exploring the Effects of Financial Marketson Linkages", Journal of Development Economic, vol. 61.

9 Investment Compact for South East Europe, January 2012 
Business development strategy and investment, 2014-2020

Borenstein, De Gregorio, E. \& Lee, J. W. 1998. "How does foreign direct investment affect economic growth"?, Journal of International Economics, vol. 45, pg. 115-135.

Campos, N. F. \& Kinoshita, Y. 2002. "FDI as Technology Transferred: Some Panel Evidence from the Transition Economies", William Davidson Working Paper, Nr 438.

Doing Business in Albania, 2014

Easterly, W. 2001. "The Lost Decades: Developing Countries' Stagnation in Spite of Policy Reform 1980-1998", Journal of Economic growth, vol. 6, pg. 135-157.

Economic Report for SEE countries, no. 3, 2012

Investment Compact for South East Europe, January 2012

Mankiw, Romer \& Weil. 1992. "A Contribution to the Empirics of Economic Growth", Quarterly Journal of Economics, pg. 407-437.

Nowbutsing, B. (2009). FDI, Domestic Investment and Economic Growth: A Theoretical Framework. Globelics 7th International Conference. Dakar, Senagal.

Overview of Macroeconomic and Fiscal Challenges in the Western Balkans and Implications for the WBIF, 2013

Solow (1956), "Contribution to the theory of Economic Growth", The quartely journal of Economics, 70(1), pg 65-94

Spahn, Vukotić dhe O'Mahony. Nëntor, 2013. Overview of Macroeconomic and Fiscal Challenges in theWestern Balkans and Implications for the WBIF. Brussels, BELGIUM: IFI.

Wang, M. 2009. "Manufacturing FDI and Economic Growth: Evidence from Asian economies", Applied Economics, pg. $991-1002$.

World Investment Report, 2013

Xu, B. 2000. "Multinational Enterprises, Technology Diffusion, and Host Country Productivity Growth", Journal of Development Economics, pg. 477-493. 